\title{
Teeth as Indicators of Environmental Pollution with Lead
}

\author{
Blerim Kamberi*, Ferit Koçani and Edmond Dragusha
}

University Dentistry Clinical Center of Kosovo, Kosovo

\begin{abstract}
Environment pollution can be determined using physical and chemical methods and with bio-indicators. In recent years there has been an increased interest on the use of human bio-indicators such as teeth, bone, blood, nail and hair to monitor environment pollution with toxic heavy metals. Therefore the determination of heavy metals content in teeth is understood to play an important role for monitoring the impact of environmental pollution. The aim of this review of literature is to illustrate the current status of teeth used as indicators in environmental pollution with lead.
\end{abstract}

Keywords: Environment; Pollution; Lead; Heavy Metals; BioIndicator; Bio-Marker

\section{Introduction}

Human civilization and concomitant increase in industrial activity have gradually influenced in redistribution of many toxic metals form the earth's crust to the surrounding environment resulting in exposure of human population. Among different toxic elements, heavy metals, lead in particular, have high prevalence in the environment. Understanding of lead toxicity has advanced substantially over the past three decades, and focus has shifted from high-dose effects in clinically symptomatic individuals to the consequences of exposure at lower doses that cause no symptoms, particularly in children and fetuses [1].

Lead is one of the most toxic elements with accumulating properties [2]. This may be due to industrialization trends in the production of pigments, anti-corrosion clothing, lead smelters and batteries causing remarkable contamination of the air, soil, water, food, sediments, etc. Therefore, determination of lead is becoming ever more important. Lead has greatly attracted researcher's attention due to its toxicity to humans. Lead intoxication in humans has neurotoxic effects such as encephalitis, behavioral disorders and inattention, reduced nerve conduction and IQ deficit $[3,4]$. A lead concentration above $4 \mathrm{mg} /$ $\mathrm{kg}$ in the teeth has been suggested as being indicative of lead toxicity $[5,6]$. Dental tissues are very hard and stable, allowing the heavy metals that are obtained from mineralization to be retained over time. Lead is incorporated and stored in calcified tissues, such as the teeth [7].

Enamel lead indicates exposure during in utero life and first post partum year, while lead in dentin indicates exposure after the tooth development [8]. Lead can be accumulated in baby teeth until they shed and it can also accumulate in permanent teeth while their presence in the mouth [9].

Teeth have an advantage over bones as biopsy tissues: they are easy to collect and are physically stable. There is evidence that teeth are superior to bone as an indicator of cumulative lead exposure because the losses from teeth are much slower as there is no turnover of apatite in teeth, as in bone, hence teeth are the most useful material for studying total past lead exposure [10].

Human teeth, both deciduous and permanent, are useful indicators of lead exposure of recent and historical populations. The use of permanent teeth is limited because the extraction of healthy permanent teeth just for this purpose is hardly acceptable [11]. Analysis of lead levels in deciduous teeth is a relatively simple and non-invasive method for determining a child's lead burden at a very young age. Since the mid 1970 's, lead levels in deciduous teeth have been used as an exposure indicator in a number of studies.
Most published data on tooth lead have been based on whole tooth analysis, with no attempt to distinguish among tooth types as different teeth are formed at different ages or to differentiate the lead concentration in enamel from that in dentin [12].

Several studies in humans have demonstrated that lead level in teeth has been used as an index of accumulation of lead and environmental pollution [13-19].

Other studies have analyzed nonhuman teeth to assess lead exposure and demonstrated that the animal species teeth are well suited as a bio-indicator for assessing lead contamination of the environment [20-27].

The lead concentrations in teeth may reflect the extent of lead exposure experienced by an individual. Other factors such as tooth type, location of the tooth in the mouth, physiological root resorption, and region of tooth-sample analyzed, may have considerable influence on the measurable lead concentration [28].

\section{Methods for the determination of lead in teeth}

Several studies have been conducted in regard to lead levels in teeth, using chemical analysis techniques and instrumental methods. However, the majority of these data is based upon non intact teeth or separated tissues of teeth such as enamel, dentin or cement.

The most common method currently used for lead analysis in biological samples (teeth) is atomic absorption Spectrophotometry (AAS) $[26,29,30]$.

Graphite furnace atomic absorption Spectrophotometry (GFAAS) is a very attractive option for the determination of trace amount of lead in teeth [10,17,31-37].

Inductively coupled plasma mass spectrometry (ICP-MS) is one of the preferred techniques for elemental analysis since it can provide

*Corresponding author: Blerim Kamberi, University Dentistry Clinical Center of Kosova; Rrethi i Spitalit p.n., 10000 Prishtina, Kosovo; Tel: +381 38512474 E-mail: blerimkamberi63@hotmail.com

Received November 04, 2011; Accepted January 09, 2012; Published January 11, 2012

Citation: Kamberi B, Koçani F, Dragusha E (2012) Teeth as Indicators of Environmental Pollution with Lead. J Environment Analytic Toxicol 2:118. doi:10.4172/2161-0525.1000118

Copyright: (c) 2012 Kamberi B, et al. This is an open-access article distributed under the terms of the Creative Commons Attribution License, which permits unrestricted use, distribution, and reproduction in any medium, provided the original author and source are credited. 
excellent sensitivity, accuracy and precision of the analysis (Figure 1). Its recent combination with laser ablation to create inductively coupled plasma-mass spectrometry (LA-ICP-MS) has increased the capabilities of this technique $[18,19,38-41]$.

Inductively coupled plasma atomic emission spectroscopy (ICPAES) is a technique similar to ICP-MS. The ICP-AES relies on an optical spectrometer for the detection of elements, rather than mass spectrometry as is the case in ICP-MS [42-44].

The laser ablation-inductively coupled plasma-mass spectrometry (LA-ICP-MS) technique is particularly useful for in-situ analyses of trace elements for applications requiring understanding of the spatial variation of elemental content within the sample [14,25,45-49].

All these techniques have been used in different modes depending upon the quantity of the sample available and elements sought.

There are only a few reference materials that are useful for quality control requirements of hard tissue analysis [50]. The animal bone CRM (IAEA H-5) issued by the International Atomic Energy Agency (IAEA) is currently out of stock. The bone ash (NIST SRM 1400) and bone meal (NIST SRM 1486) issued by the National Institute of Standards and Technology are presently available.

\section{Comparative Studies of Lead Levels in Human Teeth}

The comparison of results from various different studies is quite complex due to the lone fact of the variability of geographical origin of sample teeth, sample population, tooth type, sample preparation and analytic methodology. Also, results from various studies are hardly comparable since different parts of the teeth are analyzed. Some studies report the whole tooth others only for enamel or dentin. Nevertheless, authentic comparisons are possible.

Lead is a frequently investigated element in tooth. Many studies have been reported from several global regions. The results reported for urban areas are generally higher than those reported for nonurban environments. The differences have variously been ascribed to traffic density, the proximity of major roads, and the degree of industrialization between urban, suburban and rural areas (Table 1).

Data collected for the Kuwait, lead studies have suggested that lead levels in teeth in industrial areas are higher than in suburban areas (non-industrial) [51].

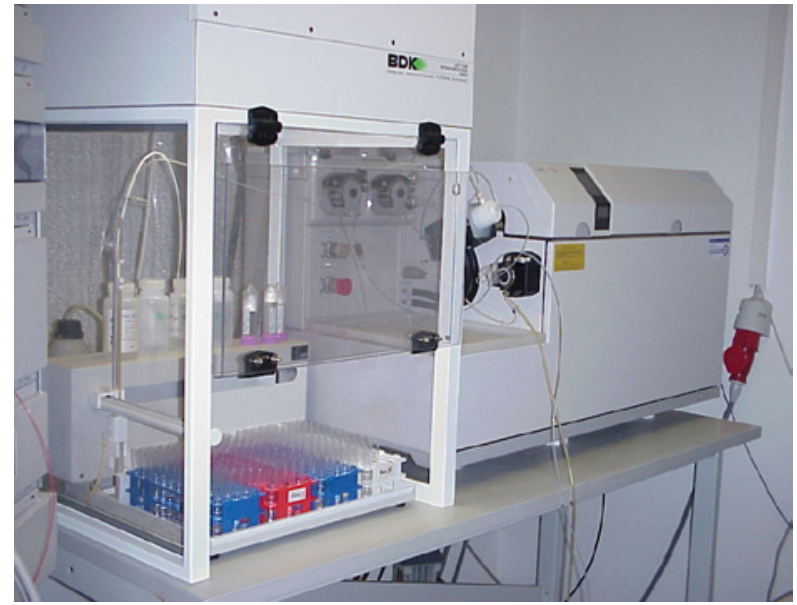

Figure 1: Inductively Coupled Plasma Mass Spectroscope (ICP-MS).
Higher levels of lead are seen in permanent teeth of juveniles near sources of increased exposure in the UK [52].

Costa de Almeida et al. [37] measured lead contents in the surface enamel of two populations one from an apparently uncontaminated area (Ribeirão Preto, São Paulo State, SP, Brazil) and the other from an area notoriously contaminated with lead (Bauru, São Paulo State, Brazil). They found that lead contents were statistically different between the Ribeirão Preto and the Bauru population $(p<0.001)$.

Arruda-Neto et al. [41] have analyzed 74 teeth on the largest city of Brazil, Sao Paulo, where concentrations of lead, copper, zinc and cadmium in sediment were found by the World Health Organization to be higher than internationally accepted limits. They found that the concentration of lead was $40 \%$ higher in the teeth taken from this area, than the control area.

Tvinnereim et al. [36] have determined the level of lead exposure in Ethiopian children in rural as well as urban areas. Teeth from Addis Ababa (urban populations) had statistically significant higher lead concentrations than teeth from the Rift Valley (rural populations).

Another study also illustrates high lead levels in teeth of populations living in the industrialized countries [19]. They show that the highest lead concentrations in human permanent teeth were in Mitrovica (22.3 $\mathrm{mg} / \mathrm{kg})$, followed by Klina $(3.1 \mathrm{mg} / \mathrm{kg})$ and $\mathrm{Graz}(1.6 \mathrm{mg} / \mathrm{kg})$. Such high concentration the authors explained with the fact that Mitrovica is an industrial area with various technological units: large smelters, refineries, flotation, battery factory and sulphuric acid production facility.

These findings suggest that lead accumulated in the teeth is linked to the environment in which people reside, indicating that this tissue should be further explored as an accessible biomarker of lead exposure.

However, there are other studies that have reported differently. Karahalil et al. [15] did not observe any significant difference between Ankara (urban) and Balıkesir (suburban) regions in Turkey. In addition, Youravong et al. [53] studied enamel and dentine in teeth of children with high blood levels of lead and compared with teeth from children with low blood levels of lead. There were no differences found in lead level in enamel of high lead level exposed teeth from low level exposed teeth.

The lead levels in whole teeth may be affected by the type of tooth. Variability of lead concentration in relation to the tooth type has been confirmed in former studies [54,55]. Even in the last decade research of lead concentration showed significant variability when comparing teeth type.

Nowak \& Chmielnicka [56] concluded a higher lead concentration in anterior teeth. Lead concentration in incisiors, canines, molars and premolars was $41.8,37.5,35.3$ and $32.0 \mu \mathrm{g} / \mathrm{g}$, respectively. Also Tvinnereim et al. [57] have found lead concentration to be significantly higher in incisors than in molars $(\mathrm{p}<0.05)$. Similarly aimed research was conducted by Bayo et al. [13] who studied the correlation of lead and cadmium contents in deciduous teeth of children from Cartagena, with some environmental and physiological factors: parental socialeconomic status, home antiquities and zone of residence, child's habits, age and sex, as well as tooth-related factors (presence of caries, type, weight and location. They have reported an increase of both heavy metals levels (cadmium and lead) - the highest being in incisors and the lowest in molars in deciduous teeth of children from Cartagena.

Rahman \& Yousuf [29] in their study evaluated chronic lead 
Citation: Kamberi B, Koçani F, Dragusha E (2012) Teeth as Indicators of Environmental Pollution with Lead. J Environment Analytic Toxicol 2:118. doi:10.4172/2161-0525.1000118

Page 3 of 5

\begin{tabular}{|c|c|c|c|c|c|}
\hline Reference [Tooth Type] & Country & Area & Sample & Analytical Method & Mean $\mathrm{Pb}$ Concentraion \\
\hline Bu-Olayan AH Thomas BV & Kuwait & Industrial & 108 & AAS & $2.38-2.50 \mu \mathrm{g} / \mathrm{g}$ \\
\hline [Primary] & & Sub-Urban & 108 & & $2.21-2.30 \mu \mathrm{g} / \mathrm{g}$ \\
\hline Costade Almeida GR, et al. (2007) & Brasil & Uncontaminated & 247 & GFASS & Median $206 \mu \mathrm{g} / \mathrm{g}$ \\
\hline [Primary] & & Contaminated & 26 & & Median $785 \mu \mathrm{g} / \mathrm{g}$ \\
\hline Karahalil B, et al. (2007) & Turkey & Sub-Urban & 279 & & $1.77 \pm 1.03 \mu \mathrm{g} / \mathrm{g}$ \\
\hline [Primary] & & Urban & & & $1.30 \pm 0.59 \mu \mathrm{g} / \mathrm{g}$ \\
\hline Arruda-Neto JD, et al. (2009) & Brasil & Sao Paulo & 74 & ICP-MS & $1.3 \mu \mathrm{g} / \mathrm{g}$ \\
\hline \multicolumn{6}{|l|}{ [Primary] } \\
\hline Kamberi B, et al. (2011) & Kosovo & Industrial & 31 & & $22.3 \mathrm{mg} / \mathrm{kg}$ \\
\hline \multirow[t]{2}{*}{ [Permanent] } & Kosovo & Non-Industrial & 32 & ICP-MS & $3.2 \mathrm{mg} / \mathrm{kg}$ \\
\hline & Austri & Non-Industrial & 23 & & $1.7 \mathrm{mg} / \mathrm{kg}$ \\
\hline
\end{tabular}

Table 1: Mean lead concentration levels in different countries.

exposure of children in Karachi and found that incisor teeth had a significantly higher mean (SD) lead level, 6.42 (4.19) micrograms/g, than canines and molars which contained 4.91 (5.12) micrograms and 4.50 (2.67) micrograms lead in whole teeth (dry weight), respectively.

Herández-Guerrero et al. [58] concluded higher lead concentration in incisors and canines than in molar and premolar teeth. The argue that according to morphological difference in size between canines and incisors including the developmental aspect od enamel and dentin formation starting in the fifth month of gestation in the maxillary canines. Also according to Karhalil et al. [15], incisors had a statistically significant higher lead level than canines and molars $(p<0.05)$.

On the contrary, Báez et al. [33] didn’t find any statistical differences for cadmium and lead concentrations when comparing tooth type. This was possibly due to the small sample size. They state that the sample size should be increased in further investigations.

\section{Conclusion}

The rate of enviromental pollution and human exposure deriving from the effects of dangerous toxic chemicals in the environment is usually difficult to assess. One possible alternative method is the use of bio-indicators to demonstrate environmental pollution. The content of trace elements in human teeth is a more suitable indicator to demonstrate environmental pollution rather then fitological and zoological sample analysis in ecological studies.

The analysis of teeth is an important technique for determining the exposure of toxic trace elements (lead). The importance of the concentration of trace elements in human teeth remains a question, considering the difficulties related to differentiate between intrinsic and extrinsic trace elements and the rationale of wide distribution of reported normal values in the literature.

Because of the ease with which samples can be collected, conveniently stored and can be readily analyzed, the analysis of teeth is valuable in screening individuals and populations for exposure to heavy metals.

However, there are three significant problem areas in the interpretation of the analytical results for lead in teeth [59]. First, the lead is not homogeneously distributed throughout the tooth; secondly, the lead levels vary with tooth type, which relates to the age of a tooth. Lastly, there are significant variations in results from different laboratories, which, in part, reflect problems with contamination, pretreatment and analytical methods.

Possibilities to address these issues are to be explored. However, considering current body of knowledge one could speculate the following.

Lead concentration levels should be evaluated considering the whole tooth rather than parts of it. As far as the individual tooth type is considered further research with bigger sample sizes are warranted, especially with permanent teeth.

Research data on age of the teeth are controversial. In areas with polluted environment, high concentration levels of lead are reached at earlier ages versus unpolluted areas were the cumulative effects of lead concentration may or may not be reached at latter age. Furthermore, a plateau of lead levels may be reached in areas with recognized environment pollution [19].

In view of the developments a standard protocol for identification of heavy metals in teeth is required.

\section{References}

1. Needleman H (2004) Lead Poisoning. Annu Rev Med 55: 209-222.

2. Chen J, Xiao S, Wu X, Fang K, Liu W (2005) Determination of lead in water samples by graphite furnace atomic absorption spectrometry after cloud point extraction. Talanta 67: 992-996.

3. Fergusson JE (1990) The heavy elements: Chemistry, environmental impact and health effects. (Oxford, New York, Seoul, Tokyo: Pergamon Press).

4. Clement IC (1993) Toxicological profile for lead (UPDATE). U.U.D.o.H.a.H Services). ed. (Atlanta GA).

5. al-Mahroos F al-Saleh FS (1997) Lead levels in deciduous teeth of children in Bahrain. Ann Trop Paediatr 17: 147-154.

6. Carvalho ML, Karydas AG, Casaca C, Zarkadas C, Paradellis T, et al. (2001) Fluorine determination in human healthy and carious teeth using the PIGE technique. Nuclear Instruments and Methods in Physics Research Section B Beam Interactions with Materials and Atoms 179: 561-567.

7. Martin RR, Naftel SJ, Nelson AJ, Feilen AB Narvaez A (2007) Metal distributions in the cementum rings of human teeth: possible depositional chronologies and diagenesis. Journal of Archaeological Science 34: 936-945.

8. Health C (1994) Blood Lead Intervention Levels and Strategies: Up of Evidence for Low-level Effects of Lead and Blood Lead Intervention Levels and Strategies. Final report of the working group. F.P.C.o.E.a.O. Heath., ed. (Ottawa).

9. Landrigan PJ (1990) Current issues in the epidemiology and toxicology of occupational exposure to lead. Environ Health Perspect 89: 61-66.

10. Grobler SR, Theunissen FS, Kotze TJ (2000) The relation between lead concentrations in human dental tissues and in blood. Archives of oral biology 45: 607-609.

11. Malara P, Kwapulinski J Malara B (2006). Do the levels of selected metals differ significantly between the roots of carious and non-carious teeth? Sci Total Environ 369: 59-68.

12. Barbosa F Jr, Tanus-Santos JE, Gerlach RF Parsons PJ (2005) A critica 
Citation: Kamberi B, Koçani F, Dragusha E (2012) Teeth as Indicators of Environmental Pollution with Lead. J Environment Analytic Toxicol 2:118. doi:10.4172/2161-0525.1000118

review of biomarkers used for monitoring human exposure to lead: advantages, limitations, and future needs. Environ Health Perspect 113: 1669-1674.

13. Bayo J, Moreno-Grau S, Martinez MJ, Moreno J, Angosto JM, et al. (2001) Environmental and physiological factors affecting lead and cadmium levels in deciduous teeth. Arch Environ Contam Toxicol 41: 247-254.

14. Arora M, Kennedy BJ, Elhlou S, Pearson NJ, Walker DM, et al. (2006) Spatial distribution of lead in human primary teeth as a biomarker of pre- and neonatal lead exposure. Sci Total Environ 371: 55-62.

15. Karahalil B, Aykanat B Ertaş N (2007) Dental lead levels in children from two different urban and suburban areas of Turkey. Int J Hyg Environ Health 210: 107-112.

16. Negrea P, Motoc M, Negrea A, Lupa L Ciopec M (2008) Quantitative Analysis of Trace Metals Accumulation in Teeth through Atomic Absorption Spectrometry. Eur Cell Mater 16: 33.

17. Olympio KPK, Naozuka J, Oliveira PV, Cardoso MRA, Bechara EJH, et al. (2010) Association of dental enamel lead levels with risk factors for environmental exposure. Rev Saúde Pública 44: 851-858.

18. Amr MA, Helal AF (2010) Analysis of Trace Elements in Teeth by ICP-MS Implications for Caries. Journal of Physical Science 21: 1-12.

19. Kamberi B, Kqiku L, Hoxha V Dragusha E (2011) Lead concentrations in teeth from people living in Kosovo and Austria. Coll Antropol 35: 79-82.

20. Appleton J, Lee KM, Sawicka Kapusta K, Damek M, Cooke M (2000) The heavy metal content of the teeth of the bank vole (Clethrionomys glareolus) as an exposure marker of environmental pollution in Poland. Environ Pollut 110: $441-449$.

21. Gdula-Argasinska J, Appleton J, Sawicka-Kapusta K Spence B (2004) Further investigation of the heavy metal content of the teeth of the bank vole as an exposure indicator of environmental pollution in Poland. Environ Pollut 131: 71-79

22. Falla-Sotelo FO, Rizzutto MA, Tabacniks MH, Added N, Barbosa MDL, et al (2005) Analysis and discussion of trace elements in teeth of different animal species. Braz. J. Phys 35: 761-762.

23. Kierdorf H, Aberg G Kierdorf U (2008) Lead concentrations and lead and strontium stable-isotope ratios in teeth of European roe deer (Capreolus capreolus). European Journal of Wildlife Research 54: 313-319.

24. Bellis DJ, Hetter KM, Jones J, Amarasiriwardena D, Parsons PJ (2008) Lead in teeth from lead-dosed goats: microdistribution and relationship to the cumulative lead dose. Environ Res 106: 34-41.

25. Copeland SR, Sponheimer M, le Roux PJ, Grimes V, Lee-Thorp JA, et al (2008) Strontium isotope ratios $(87 \mathrm{Sr} / 86 \mathrm{Sr})$ of tooth enamel: a comparison of solution and laser ablation multicollector inductively coupled plasma mass spectrometry methods. Rapid Commun Mass Spectrom 22: 3187-3194.

26. Todorovic T, Vujanovic D, Dozic I, Petkovic-Curcin A (2008) Calcium and magnesium content in hard tissues of rats under condition of subchronic lead intoxication. Magnes Res 21: 43-50.

27. Ando N, Isono T, Sakurai Y (2005) Trace elements in the teeth of Steller sea lions (Eumetopias jubatus) from the North Pacific. Ecol Res 20: 415-423.

28. Arora M (2005) The Spatial Distribution of Lead in Teeth as a Biomarker of Prenatal and Neonatal Lead Exposure. (Sidney: University of Sidney).

29. Rahman A Yousuf FA (2002) Lead levels in primary teeth of children in Karachi. Ann Trop Paediatr 22: 79-83.

30. Alomary A, Al-Momani IF, Massadeh AM (2006) Lead and cadmium in human teeth from Jordan by atomic absorption spectrometry: Some factors influencing their concentrations. Sci Total Environ 369: 69-75.

31. Tsuji LJ, Karagatzides JD, Katapatuk B, Young J, Kozlovic DR, et al. (2001) Elevated dentine-lead levels in deciduous teeth collected from remote first nation communities located in the western James Bay region of northern Ontario, Canada. J Environ Monit 3: 702-705.

32. Báez A, Belmont R, Espinosa S, García R, Hernández C (2002) Lead absorption in impacted third molars. Rev Int Contam Ambient 18: 75-79.

33. Báez A, Belmont R, Garcia R Hernández C (2004) Cadmium anf lead levels in deciduous teeth of children living in Mexico City. Rev Int Contam Ambient 20: $109-115$.
34. Barton HJ (2011) Advantages of the use of deciduous teeth, hair, and blood analysis for lead and cadmium bio-monitoring in children. A study of 6 -year-old children from Krakow (Poland). Biol Trace Elem Res 143: 637-658.

35. Zhang C, Wang Y, Cheng X, Xiaa H Liang P (2011) Determination of Cadmium and Lead in Human Teeth Samples Using Dispersive Liquid-liquid Microextraction and Graphite Furnace Atomic Absorption Spectrometry. J Chin Chem Soc 58

36. Tvinnereim HM, Fantaye W, Isrenn R, Bjorvatn K, Melaku Z, et al. (2011) Lead levels in primary teeth in children from urban and rural areas in Ethiopia. Ethiop Med J 49: 61-66.

37. Costa de Almeida GR, Pereira Saraiva Mda C, Barbosa F Jr, Krug FJ, Cury JA et al. (2007) Lead contents in the surface enamel of deciduous teeth sampled in vivo from children in uncontaminated and in lead-contaminated areas. Environ Res 104: 337-345.

38. Grunke K, Stark HJ, Wennrich R Franck U (1996) Determination of traces of heavy metals $(\mathrm{Mn}, \mathrm{Cu}, \mathrm{Zn}, \mathrm{Cd}$ and $\mathrm{Pb})$ in microsamples of teeth material by ETV-ICP-MS. Anal Bioanal Chem 354: 633-635.

39. Reitznerova E, Amarasiriwardena D, Kopcakova M, Barnes RM (2000) Determination of some trace elements in human tooth enamel. Fresenius $\mathrm{J}$ Anal Chem 367: 748-754

40. Brown CJ, Chenery SR, Smith B, Tomkins A, Roberts GJ, et al. (2002) A sampling and analytical methodology for dental trace element analysis. Analyst 127: 319-323.

41. Arruda-Neto JD, de Oliveira MC, Sarkis JE, Bordini P, Manso-Guevara MV et al. (2009) Study of environmental burden of lead in children using teeth as bioindicator. Environ Int 35: 614-618.

42. Chew LT, Bradley DA, Mohd AY Jamil MM (2000) Zinc, lead and copper in human teeth measured by induced coupled argon plasma atomic emission spectroscopy (ICP-AES). Appl Radiat Isot 53: 633-638.

43. Webb E, Amarasiriwardena D, Tauch S, Green EF, Jones J, et al. (2005) Inductively coupled plasma-mass (ICP-MS) and atomic emission spectrometry (ICP-AES): Versatile analytical techniques to identify the archived elemental information in human teeth. Microchemical Journal 81: 201-208.

44. Hegde S, Sridhar M, Bolar DR, Bhaskar SA, Sanghavi MB (2010) Relating tooth- and blood-lead levels in children residing near a zinc-lead smelter in India. Int J Paediatr Dent 20: 186-192.

45. Uryu T, Yoshinaga J, Yanagisawa Y, Endo M, Takahashi J (2003) Analysis of lead in tooth enamel by laser ablation-inductively coupled plasma-mass spectrometry. Anal Sci 19: 1413-1416.

46. Kang D, Amarasiriwardena D Goodman AH (2004) Application of laser ablationinductively coupled plasma-mass spectrometry (LA-ICP-MS) to investigate trace metal spatial distributions in human tooth enamel and dentine growth layers and pulp. Anal Bioanal Chem 378: 1608-1615.

47. Dolphin AE, Goodman AH, Amarasiriwardena DD (2005) Variation in elemental intensities among teeth and between pre- and postnatal regions of enamel. Am J Phys Anthropol 128: 878-888.

48. Castro W, Hoogewerff J, Latkoczy C, Almirall JR (2010) Application of lase ablation (LA-ICP-SF-MS) for the elemental analysis of bone and teeth samples for discrimination purposes. Forensic Sci Int 195: 17-27.

49. Abdullah MM, Ly AR, Goldberg WA, Clarke-Stewart KA, Dudgeon JV, et al. (2011) Heavy Metal in Children's Tooth Enamel: Related to Autism and Disruptive Behaviors? J Autism Dev Disord.

50. lyengar GV Tandon L (1999) Minor and trace elements in bones and teeth (Vienna: International Atomic Energy Agency- Section of Nutritional and Health-Related Environmental Studies)

51. Bu-Olayan AH, Thomas BV (1999) Dental lead levels in residents from industrial and suburban areas of Kuwait. Sci Total Environ 226: 133-137.

52. James PR, Close JJ, Keitch PA, Allen JE, Fews AP, et al. (2004) Aspects of the geographical variations of naturally occurring $210 \mathrm{~Pb} / 210 \mathrm{Po}$ in permanent teeth of juveniles in the UK. Int J Radiat Biol 80: 199-208.

53. Youravong N, Teanpaisan R, Noren JG, Robertson A, Dietz W, et al. (2008) Chemical composition of enamel and dentine in primary teeth in children from Thailand exposed to lead. Sci Total Environ 389: 253-258.

54. Rabinowitz MB, Leviton A, Bellinger DC (1989) Blood lead--tooth lead relationship among Boston children. Bull Environ Contam Toxicol 43: 485-492. 
Citation: Kamberi B, Koçani F, Dragusha E (2012) Teeth as Indicators of Environmental Pollution with Lead. J Environment Analytic Toxicol 2:118. doi:10.4172/2161-0525.1000118

Page 5 of 5

55. Alexander LM, Heaven A, Delves HT, Moreton J Trenouth MJ (1993) Relative exposure of children to lead from dust and drinking water. Arch Environ Health 48: 392-400.

56. Nowak B, Chmielnicka J (2000) Relationship of lead and cadmium to essentia elements in hair, teeth, and nails of environmentally exposed people. Ecotoxicol Environ Saf 46: 265-274.

57. Tvinnereim HM, Eide R, Riise T (2000) Heavy metals in human primary teeth: some factors influencing the metal concentrations. Sci Total Environ 255: 21 27 .

58. Hernandez-Guerrero JC, Jimenez-Farfan MD, Belmont R, Ledesma-Montes C Baez A (2004) Lead levels in primary teeth of children living in Mexico City. Int J Paediatr Dent 14: 175-181.

59. Fergusson JE, Purchase NG (1987) The analysis and levels of lead in human teeth: a review. Environ Pollut 46: 11-44. 